\title{
Establishment and Early Yield Development of Five Possible Alternatives to Trifolium repens as a Grassland Legume
}

\author{
Kai Küchenmeister ${ }^{1,2}$, Frank Küchenmeister ${ }^{1,2}$, Nicole Wrage ${ }^{3}$, Manfred Kayser ${ }^{1} \&$ Johannes Isselstein $^{1,2}$ \\ ${ }^{1}$ Department of Crop Sciences, Georg-August-University Goettingen, Goettingen, Germany \\ ${ }^{2}$ Centre of Biodiversity and Sustainable Land Use, Georg-August-University Goettingen, Goettingen, Germany \\ ${ }^{3}$ Faculty of Life Science, Rhine-Waal University of Applied Sciences, Kleve, Germany \\ Correspondence: Kai Küchenmeister, Department of Crop Sciences, Georg-August-University Goettingen, \\ Goettingen, von-Siebold-Str. $\quad 8, \quad$ Germany. Tel: 49-551-394-357. E-mail: \\ kai.kuechenmeister@agr.uni-goettingen.de
}

Received: April 11, 2012 Accepted: April 28, 2012 Online Published: July 11, 2012

doi:10.5539/jas.v4n8p86 URL: http://dx.doi.org/10.5539/jas.v4n8p86

\begin{abstract}
The performance of Trifolium repens as the main grassland legume in temperate climates may decrease under climate change due to more frequent water shortages. This calls for alternative legumes with agronomic potential. We examined germination rates, establishment, winter tolerance and yield potential of Medicago lupulina, Medicago falcata, Lotus corniculatus, Lotus uliginosus and Onobrychis viciifolia both in monoculture and in mixture with Lolium perenne in a two-year container experiment. Germination and establishment of all alternative legumes were comparable to T. repens except of M. falcata with a retarded initial development. L. uliginosus was the only species with an insufficient winter tolerance. In pure stands M. lupulina and L. corniculatus showed a yield potential almost as high as of $T$. repens. However, their performance in mixture with $L$. perenne was lower than $T$. repens. This has to be considered with the choice of less competitive grass partner species when designing seed mixtures.
\end{abstract}

Keywords: Lotus corniculatus, Lotus uliginosus, Medicago lupulina, Medicago falcata, Onobrychis viciiifolia, Lolium perenne, winter tolerance, early development

\section{Introduction}

Legumes are important for grassland productivity, especially in swards with low or no nitrogen $(\mathrm{N})$ fertilisation due to their ability to fix atmospheric N. Nevertheless, in conventional agriculture in Europe the proportion of forage legumes in swards has decreased in the last decades (Peeters, 2009) mainly because of the ready availability of inorganic N-fertilizer (Rochon et al., 2004). However, with increasing energy and N-fertilizer prices along with higher costs for concentrates, the use of grassland legumes becomes more attractive (Jensen \& Hauggaard-Nielsen, 2003; Crews \& Peoples, 2005).

The main fodder legume in grasslands in Central Europe is Trifolium repens (Frame, Charlton, \& Laidlaw, 1998). Under appropriate climatic conditions, $T$. repens/grass mixtures can produce high yields and a good fodder quality (Wilman \& Williams, 1993; Wilkins, Gibb, Huckle, \& Clements, 1994; Topp \& Doyle, 2004). However, T. repens has been shown to need a good supply of water for growth (Foulds, 1978). This may become challenging in times of climate change, as summer rainfall is predicted to become sparse (Alcamo et al., 2007).

Other legumes may be better adapted to drier conditions or have special feeding values and may therefore have potential as alternatives for $T$. repens. Currently, the agronomic knowledge, including early stages of establishment in monoculture and in mixture with grasses, of other legumes of permanent grasslands is limited (Hopkins, Martyn, Johnson, Sheldrick, \& Lavender, 1996; Rochon et al., 2004; Hopkins \& Wilkins, 2006; Sölter, Hopkins, Sitzia, Goby, \& Greef, 2007) and their cultivation and use insignificant. Early development determines to a great deal the successful establishment and yield contribution of legumes especially when sown in mixture with grasses (Petersen, 1967).

In this study, we therefore tested the agronomic potential in early development of five promising grassland legumes (Table 1) against $T$. repens. A container experiment was conducted in a vegetation hall from 2009 to 2010. All legumes were sown in monoculture and in mixture with Lolium perenne. The climatic conditions in the 
vegetation hall followed a normal seasonal pattern with frost in winter and higher temperatures in summer. We considered the germination rates, establishment, the response to a winter stress phase and the yield potential in the sowing and first main production year.

Table 1. Used plant species, cultivars, seed weight, ecological strategy types, tolerances (mowing, grazing, trampling) and nutritive values of all species

\begin{tabular}{|c|c|c|c|c|c|c|c|}
\hline \multirow[t]{2}{*}{ Plant species } & \multirow[t]{2}{*}{ Cultivar } & \multirow{2}{*}{$\begin{array}{c}\text { Seed } \\
\text { weight } \\
{[\mathrm{mg}]}\end{array}$} & \multirow{2}{*}{$\begin{array}{l}\text { Strategy } \\
\text { type }\end{array}$} & \multicolumn{3}{|c|}{ Tolerance } & \multirow{2}{*}{$\begin{array}{c}\text { Nutritive } \\
\text { value }^{2}\end{array}$} \\
\hline & & & & Mowing $^{3}$ & Grazing $^{2}$ & Trampling $^{2}$ & \\
\hline Lotus corniculatus & Bull & 1.45 & $\operatorname{csr}$ & 6 & 4 & 4 & 8 \\
\hline Lotus uliginosus & wild seeds & 0.74 & $\operatorname{csr}$ & 4 & 4 & 4 & 7 \\
\hline Medicago lupulina & Ekola & 1.69 & $\operatorname{csr}$ & 7 & 4 & 6 & 8 \\
\hline Medicago falcata & wild seeds & 0.95 & cs & 5 & 2 & 2 & 7 \\
\hline Onobrychis viciifolia & Matra & 21.90 & $\mathrm{c}$ & 6 & 2 & 2 & 8 \\
\hline Trifolium repens & Rivendel & 0.62 & $\operatorname{csr}$ & 8 & 8 & 8 & 9 \\
\hline Lolium perenne & Signum & 2.75 & $\mathrm{c}$ & 8 & 8 & 8 & 9 \\
\hline
\end{tabular}

${ }^{1}$ according to Klotz, Kühn and Durka (2002); c: competitor. s: stress tolerator. r: ruderal

2 according to Dierschke and Briemle (2002); values range from 1 (low) to 9 (high)

3 according to Briemle and Ellenberg (1994); values range from 1 (low) to 9 (high)

\section{Material and Methods}

The experiment consisted of a germination test and a container experiment with six legumes and the grass Lolium perenne. Both, wild flower seeds and cultivars were used depending on the availability (Table 1). The trial was separated into three phases: germination and establishment (establishment phase), effects of lower temperatures and short days (winter stress phase) and the first main production year (initial yield phase).

\subsection{Germination Test}

For the germination test, 30 seeds of each species were sown on Petri dishes $(9 \mathrm{~cm}$ diameter, bottom covered with two pieces of moistened filter paper, Schleicher and Schuell Microscience). The lids were replaced and fastened with laboratory film (American National Can). Five replicate dishes for each species were arranged in a randomized block design in a greenhouse (night temperatures: 13 to $16^{\circ} \mathrm{C}$, day temperatures 21 to $26^{\circ} \mathrm{C}$, no extra lighting, germination between February $8^{\text {th }}$ and March $4^{\text {th }} 2009$ ). Every two days, germinated seeds (with visible radicles) were counted and removed. The filter paper was kept moist (tap water).

\subsection{Container Experiment}

\subsubsection{Experimental Setup}

The container experiment was set up in 2009, sowing date was July $15^{\text {th }}$. For this experiment, 301 containers (diameter $33 \mathrm{~cm}$, height $42 \mathrm{~cm}$ ) were filled with a homogeneous mixture of $20 \mathrm{~kg}$ air-dried sand (sieved to pass a mesh of $5 \mathrm{~mm}$; August Oppermann Kiesgewinnung $\mathrm{GmbH}$ ), $0.9 \mathrm{~kg}$ vermiculite (particle size 8-12 mm; Deutsche Vermiculite $\mathrm{GmbH}$ ) and $5.5 \mathrm{~kg}$ compost (air dried; Bioenergiezentrum Göttingen $\mathrm{GmbH}$ ) and covered with $1.5 \mathrm{~kg}$ compost as a seed bed. The six legumes and L. perenne were sown in monoculture $\left(1000\right.$ germinable seeds per $\mathrm{m}^{2}$ for legumes and 5000 for the grass) and the legumes also in mixture with L. perenne (half the amount of seeds of each species sown in monoculture). This resulted in 13 treatments, which were replicated four times, leading to 52 containers that were arranged in a randomized block design in a vegetation hall.

The minimum and maximum air temperatures were recorded daily at three locations distributed over the vegetation hall (Table 2) and temperatures adjusted by venting in summer and heating on frost days in winter (temperature should not fall below $0^{\circ} \mathrm{C}$ for more than $24 \mathrm{~h}$ ). Nevertheless, L. uliginosus was strongly reduced in all containers during winter and had to be resown at full seed strength in March 2010. There was no extra lighting in the vegetation hall and lighting conditions followed seasonal patterns. No fertilisation took place, but all plots were treated with rhizobium solution (Radicine, Jost GmbH) three times in 2009 and twice in 2010 (per application, 
$0.015 \mathrm{ml}$ Radicine mixed with $250 \mathrm{ml}$ tap water per $\mathrm{m}^{2}$ ). The Radicin solution mixture contained all rhizobia strains in same proportions for an effective infection of all legumes. Containers were kept moist during germination of the seeds. Starting two weeks after sowing, all containers were weighed regularly and irrigated when the water content was below $50 \%$ of field capacity.

Table 2. Temperatures $\left[{ }^{\circ} \mathrm{C}\right]$ in the vegetation hall from July 2009 until October 2010

\begin{tabular}{llc}
\hline Year & Month & $\begin{array}{c}\text { Average minimum - } \\
\text { maximum temperature }\end{array}$ \\
\hline \multirow{2}{*}{2009} & July & $14-31$ \\
& August & $14-33$ \\
& September & $13-32$ \\
& October & $6-25$ \\
& November & $6-14$ \\
& December & $-1-8$ \\
\hline \multirow{4}{*}{2010} & January & $-1-5$ \\
& February & $0-14$ \\
& March & $5-25$ \\
& April & $6-29$ \\
& May & $9-26$ \\
& June & $12-35$ \\
& July & $16-36$ \\
August & $15-33$ \\
& September & $11-26$ \\
October & $6-24$ \\
\hline
\end{tabular}

\subsubsection{Sampling}

The aboveground biomass was harvested two times in 2009 and five times in 2010. Harvesting took place 50 (establishment phase), 104, 272 (winter stress phase), 315, 356, 407, and 462 (yield phase) days after sowing. Shoots were cut 3-4 cm above the soil surface. Biomass of mixtures was sorted into species directly after harvesting. All samples were dried at $60^{\circ} \mathrm{C}$ for $72 \mathrm{~h}$ and weighed.

\subsection{Statistical Analysis of Data}

Statistical data analysis was carried out using the Genstat 6.1 software package. Analysis of variance (ANOVA) considered one factor. Residuals were used to check the validity of the models. Normality in data was achieved by applying logarithmic or square root transformations, if necessary. Where significant treatment effects $(\alpha<0.05)$ were found by ANOVA, least significant differences (Tukey Test) were used to compare mean values. Relationships between legume dry matter yield in monocultures and mixtures of the first harvest, in monocultures before and after winter and between the accumulated yield of the legume partner and the total mixture yield in the first main harvest year were examined with a linear regression model.

\section{Results}

\subsection{Establishment Phase}

The germination rate after 24 days on petri dishes ranged from 34\% (M. falcata) and 100\% (M. lupulina, Table 3). There were significant differences between M. falcata, the two Lotus species, which formed an intermediate group, and the other legumes, which had germination rates between 88 and $100 \%(P<0.001)$. The germination rate of the grass $L$. perenne was $93 \%$ and similar to that of the latter group of legumes. 
The dry matter yield of the legumes in pure stands during the establishment phase (50 days after sowing) ranged from $5.0 \mathrm{~g} \mathrm{pot}^{-1}$ to $16.0 \mathrm{~g} \mathrm{pot}^{-1}$ for $M$. falcata and O. viciifolia, respectively (Table 3). Yields of the other legumes were intermediate, with $L$. corniculatus, M. lupulina and T. repens producing similar yields to $O$. viciifolia, and $L$. uliginosus being closer to the low yielding M. falcata. For comparison L. perenne produced in pure stands $27.8 \mathrm{~g}$ pot $^{-1}$ in that first harvest. Mixtures of the single legumes and L. perenne did not differ in dry matter yield $(P=0.144)$. Yield in mixtures was generally larger than in legume monocultures, but smaller than that of $L$. perenne in pure stand. The contribution of the legume partner to the total yield in mixture varied significantly among species $(P<0.001)$, with yields increasing in the order L. uliginosus, M. falcata, T. repens, M. lupulina, L. corniculatus, and $O$. viciifolia.

Table 3. Germination rate after 24 days [\%] on Petri dishes and dry matter yield of all species in pure and mixed stands (total yield and yield of the legume partner in the mixture) of the container experiment at the first harvest (Establishment phase).

\begin{tabular}{lcccc}
\hline \multirow{2}{*}{ Plant species } & $\begin{array}{c}\text { Germination after 24 } \\
\text { days [\%] }\end{array}$ & \multicolumn{2}{c}{ Dry matter yield $\left[\mathrm{g} \mathrm{pot}^{-1}\right]$} \\
\cline { 3 - 5 } & & Pure stand & \multicolumn{2}{c}{ Mixed stand } \\
\cline { 3 - 5 } & & & Total & Legume \\
\hline L. corniculatus & $73 \pm 4^{\mathrm{b}}$ & $14.3 \pm 4.5^{\mathrm{ab}}$ & $20.8 \pm 1.1$ & $2.3 \pm 0.3^{\mathrm{b}}$ \\
L. uliginosus & $71 \pm 8^{\mathrm{b}}$ & $9.1 \pm 1.4^{\mathrm{bc}}$ & $19.6 \pm 1.9$ & $0.1 \pm<0.1^{\mathrm{f}}$ \\
M. lupulina & $100 \pm 0^{\mathrm{a}}$ & $11.8 \pm 2.0^{\mathrm{ab}}$ & $25.8 \pm 3.8$ & $1.6 \pm 0.2^{\mathrm{c}}$ \\
M. falcata & $34 \pm 10^{\mathrm{c}}$ & $5.0 \pm 1.2^{\mathrm{c}}$ & $22.5 \pm 1.4$ & $0.3 \pm 0.1^{\mathrm{e}}$ \\
O. viciifolia & $89 \pm 7^{\mathrm{a}}$ & $16.0 \pm 2.1^{\mathrm{a}}$ & $22.1 \pm 4.9$ & $4.0 \pm 0.5^{\mathrm{a}}$ \\
T. repens & $88 \pm 5^{\mathrm{a}}$ & $11.4 \pm 0.7^{\mathrm{ab}}$ & $21.5 \pm 2.2$ & $1.0 \pm 0.3^{\mathrm{d}}$ \\
\hline L. perenne & $93 \pm 3$ & $27.8 \pm 2.4$ & & \\
\hline$P$-value & $<0.001$ & $<0.001$ & 0.144 & $<0.001$ \\
\hline
\end{tabular}

Shown are means and standard deviations. Different superscript letters indicate significant differences among species (ANOVA with Tukey Test $(a<0.05)$ analysis; the last row gives the corresponding $P$-values). $L$. perenne was not included in the statistics.

\subsection{Winter Stress Phase}

The winter phase lasted from beginning of November 2009 to early March 2010. Low temperatures (Table 2) associated with low radiation and short days limited plant growth similar to field conditions. Frost occurred but temperatures were prevented from falling below $0^{\circ} \mathrm{C}$ for more than $24 \mathrm{~h}$.

To evaluate the effects of the winter phase the last harvest in 2009 (end of October) and the first harvest in 2010 (mid of April) were considered. For the harvest in October 2009, the legumes growing in pure stands showed two distinctive groups $(P<0.001)$ : a high-yielding group consisting of L. uliginosus, T. repens and M. lupulina, with yields between 27.1 and $34.4 \mathrm{~g} \mathrm{pot}^{-1}$, and a low-yielding group of M. falcata, L. corniculatus, and O. viciifolia, with yields between 7.8 and $15.2 \mathrm{~g} \mathrm{pot}^{-1}$ (Table 4). At the harvest in April 2009, the dry matter yields of most legumes in pure stand (apart from L. uliginosus) were similar to or larger than before winter. While L. uliginosus produced only $0.4 \mathrm{~g} \mathrm{pot}^{-1}$, a significantly smaller yield than all other legumes $(P<0.001$; Table 4$), M$. falcata, $O$. viciifolia and L. corniculatus showed intermediate yields of 21.6- $29.9 \mathrm{~g} \mathrm{pot}^{-1}$ and M. lupulina and T. repens were again the highest-yielding legumes (34.4 and $37.0 \mathrm{~g} \mathrm{pot}^{-1}$, respectively).

Total yields in mixed stands of legume and L. perenne before winter were largest in containers containing $M$. lupulina, the only legume besides T. repens that managed to produce appreciable amounts of biomass in this phase (Table 4). Containers with M. falcata or $O$. viciifolia as legume partner produced significantly less total biomass before winter $(P=0.005)$, while yields of mixtures with $L$. uliginosus and $L$. corniculatus were intermediate. The yield contribution of the legume was smallest for L. uliginosus and also M. falcata and L. corniculatus, while only M. lupulina and T. repens produced considerable amounts of biomass. After winter, differences in biomass 
production of the mixtures were not significant $(P=0.678)$. At that time only $T$. repens produced an appreciable yield of $3.7 \mathrm{~g} \mathrm{pot}^{-1}$, significantly larger than that of any other legume in mixture.

Table 4. Dry matter yield of all species in pure and mixed stands with L. perenne (total yield and yield of the legume partner in the mixture) at the last harvest before winter in 2009 and the first harvest after winter in spring 2010 (Winter stress phase)

\begin{tabular}{|c|c|c|c|c|c|c|}
\hline \multirow[t]{4}{*}{ Plant species } & \multicolumn{6}{|c|}{ Dry matter yield $\left[\mathrm{g} \mathrm{pot}^{-1}\right]$} \\
\hline & \multicolumn{2}{|c|}{ Pure stand } & \multicolumn{4}{|c|}{ Mixed stand } \\
\hline & \multirow[b]{2}{*}{ Before winter } & \multirow[b]{2}{*}{ After winter } & \multicolumn{2}{|c|}{ Total } & \multicolumn{2}{|c|}{ Legume } \\
\hline & & & Before winter & After winter & Before winter & After winter \\
\hline L. corniculatus & $15.2 \pm 2.8^{\mathrm{b}}$ & $25.6 \pm 4.1^{\mathrm{ab}}$ & $30.2 \pm 2.6^{\mathrm{ab}}$ & $33.3 \pm 5.6$ & $0.4 \pm 0.1^{\mathrm{b}}$ & $0.5 \pm 0.4^{\mathrm{b}}$ \\
\hline L. uliginosus & $27.1 \pm 6.6^{\mathrm{a}}$ & $0.4 \pm 0.4^{\mathrm{c}}$ & $32.5 \pm 1.1^{\mathrm{ab}}$ & $34.1 \pm 2.4$ & $<0.1 \pm 0.1^{\mathrm{c}}$ & $<0.1 \pm<0.1^{\mathrm{b}}$ \\
\hline M. lupulina & $34.4 \pm 2.7^{\mathrm{a}}$ & $34.4 \pm 5.6^{\mathrm{a}}$ & $35.3 \pm 2.0^{\mathrm{a}}$ & $32.8 \pm 3.2$ & $3.1 \pm 1.3^{\mathrm{a}}$ & $0.5 \pm 0.1^{\mathrm{b}}$ \\
\hline M. falcata & $7.8 \pm 5.3^{\mathrm{b}}$ & $21.6 \pm 4.2^{b}$ & $28.2 \pm 2.1^{\mathrm{b}}$ & $35.0 \pm 3.8$ & $0.1 \pm 0.1^{\mathrm{c}}$ & $0.2 \pm 0.1^{\mathrm{b}}$ \\
\hline O. viciifolia & $12.9 \pm 0.5^{\mathrm{b}}$ & $29.9 \pm 3.1^{\mathrm{ab}}$ & $27.9 \pm 4.0^{\mathrm{b}}$ & $33.9 \pm 2.5$ & $0.8 \pm 0.2^{\mathrm{ab}}$ & $0.1 \pm<0.1^{\mathrm{b}}$ \\
\hline T. repens & $32.4 \pm 5.4^{\mathrm{a}}$ & $37.0 \pm 10.9^{\mathrm{a}}$ & $33.2 \pm 1.3^{\mathrm{ab}}$ & $36.8 \pm 3.5$ & $3.5 \pm 2.2^{\mathrm{a}}$ & $3.7 \pm 2.4^{\mathrm{a}}$ \\
\hline L. perenne & $26.1 \pm 3.7$ & $35.9 \pm 2.4$ & & & & \\
\hline$P$-value & $<0.001$ & $<0.001$ & 0.005 & 0.678 & $<0.001$ & $<0.001$ \\
\hline
\end{tabular}

Shown are means and standard deviations. Different superscript letters indicate significant differences among species (ANOVA with Tukey Test $(a<0.05)$ analysis; the last row gives the corresponding $P$-values). L. perenne was not included in the statistics.

\subsection{Initial Yield Phase}

The yield phase comprises of four harvests in the first main production year following the initial harvest after winter. The accumulated yield of the pure stands over the four main harvests 2010 ranged from 88.1 to $288.6 \mathrm{~g}$ $\operatorname{pot}^{-1}$. It was smallest for $O$. viciifolia and L. uliginosus, significantly larger for $M$. falcata and L. corniculatus and largest for $T$. repens with $M$. lupulina being intermediate $(P<0.001$, Table 5). Accumulated yield of mixed stands was by far largest for mixtures with $T$. repens, followed by those with M. lupulina and L. corniculatus. In mixed stands $L$. uliginosus and $O$. viciifolia as the legume partner did not produce any biomass. Yield contribution of $T$. repens was largest with 0.59 (149.0 $\left.\mathrm{g} \mathrm{pot}^{-1}\right)$, while that of M. lupulina, L. corniculatus and M. falcata amounted to $0.26,0.16$ and 0.08 , respectively. In pure stands the coefficient of variation $(\mathrm{CV})$, as a measure of the yield variability among harvests, was largest for M. falcata, L. corniculatus, and M. lupulina and significantly smaller for O. viciifolia $(P<0.001$, Table 5). Generally, mixtures had a smaller CV than pure stands of legumes (Table 5). Greatest variability in yields between harvests $(\mathrm{CV}, P<0.001)$ was observed for the mixture with $T$. repens with a $\mathrm{CV}$ of 0.34 which was significantly larger than that of L. uliginosus, M. lupulina, M. falcata and O. viciifolia ranging from $0.18-0.21$; L corniculatus was intermediate with 0.24 . Coefficients of variation considering the yields of the legume partner in mixtures were high and in a range from $0.71-0.95$ but differences between legumes not significant $(P=0.395)$.

\section{Discussion}

We compared five legumes as alternatives to T. repens in early development as pure stands and in mixture with $L$. perenne. To be agronomically competitive, it is important that legumes have a good establishment, show good winter tolerance, can perform in mixtures with partner species (here L. perenne) and thus provide good yields.

\subsection{Establishment Phase}

Generally, cultivated legumes had larger germination rates than wild seeds (L. uliginosus and M. falcata, Table 3). Especially M. falcata, from wild seeds, had very poor germination rates, with only $34 \%$ of seeds germinated after 24 days (Table 3). This was likely due to a higher percentage of hard seed. Medicago species may have up to $100 \%$ hard seed, depending on the habitat (Young, Evans, \& Kay, 1970; Crawford, Lake, \& Boyce, 1989). Hard seed coats help to survive unfavourable environmental conditions like long droughts (Kemp, 1989), but also influence both, water uptake and germination rate (Argel \& Paton, 1999; Uzun \& Aydin, 2004). Mechanical scarification 
may have increased germination of M. falcata. However, in the present experiment, we accounted for low germination rates by adapting the sowing density. The German Regulation for Seeds (Saatgutverordnung, 2006), requires a good and homogeneous germination for cultivars, consequently resulting in a smaller share of seeds with hard seed coats. This may have lead to the larger germination rates of the tested cultivars compared to the wild seeds. While germination is better in cultivars, the ability to survive periods of drought might be reduced and the timing of sowing and weather conditions during germination becomes more important. In the first harvest 50 days after sowing, cultivars also had larger dry matter yields than the wild type legumes both in monoculture and mixture (Table 3). Tauro, Nezomba, Mtambanengwe and Mapfumo (2009) observed similar results in their study. The size of seeds also has an effect on plant establishment; large-seeded species have often been found to have a better seedling establishment than small-seeded ones (Moles \& Westoby, 2004), because of larger nutrient reserves in heavier seeds (Baker, 1972). This could only be confirmed in part in our experiment (Table 1 and Table 3 ): The species with the largest seeds, $O$. viciifolia, produced the largest biomass at the first harvest, both in pure stands and in mixtures. However, the large difference in seed weight between $O$. viciifolia and the next two legumes, M. lupulina and L. corniculatus (Table 1) was not reflected in large differences in yield (Table 3). Furthermore, M. lupulina and T. repens produced similar amounts of dry matter (Table 3 ) despite seed weights differing by a factor of 2.7 (Table 1). The absence of a strong relationship between seed weight and dry matter yield during the establishment might partly be explained by the use of wild seeds and cultivars for different legume species.

In mixtures, $L$. perenne was the main contributor to dry matter yields at the first harvest (Table 3 ). This was both due to the fast growth of $L$. perenne (Petersen, 1967) and the relatively high seed density of the grass compared to the legumes, deliberately chosen to test the competitive strength of the legumes. There was a positive linear correlation between the dry matter yield of legumes in monoculture and that in mixture $\left(R^{2}=0.75 ; P=0.026\right)$. But, neither germination rate nor seed weight were good explanatory factors for the ability of species to compete in mixtures.

To sum up, O. viciifolia and M. lupulina did compete well with T. repens in germination rates. In terms of dry matter yield at the first harvest, $O$. viciifolia and M. lupulina again, but also L. corniculatus, were similar or even superior to $T$. repens. In mixtures with $L$. perenne, these three legumes produced significantly more biomass than T. repens at the first harvest. However, total yields in mixtures were only slightly larger and differences not significant (Table 3).

\subsection{Winter Stress Phase}

For legumes, the winter period is a crucial and sensitive phase, especially in newly established swards (Brandsæter, Smeby, Tronsmo, \& Netland, 2000). All legumes in monoculture in this study, apart from $L$. uliginosus, survived the winter period well (Table 4). This is partly due to the conditions of a vegetation hall where moderate frost occurred, but long-term and sharp frost was prevented (Table 2). Results of only moderate winter tolerance for L. uliginosus have been reported before (Hedqvist, Murphy, \& Nilsdotter-Linde, 2002). In line with that, the good winter tolerance found for M. falcata, M. lupulina, T. repens, L. corniculatus and O. viciifolia is in agreement with earlier findings (Frame et al., 1998; Brandsæter et al., 2000; Hedqvist et al., 2002). This was confirmed by a positive linear correlation between the dry matter yield of legumes in monocultures before and after winter $\left(R^{2}=0.83 ; P=0.033\right.$, L. uliginosus not considered). Two legumes, M. lupulina and $T$. repens, had a fast establishment in the sowing year and a corresponding early development in the next spring, which was the basis for good yields in the first main production year. This is consistent with Petersen (1967).

As in the first harvest, L. perenne was the dominant plant in all mixtures in the harvests before and after winter (Table 4) - with the exception of $T$. repens, the yield of all legume partners in mixtures was well below one gram in the first harvest after winter (Table 4). This can be explained by a good and fast growth of L. perenne (Petersen, 1967) and temperatures that were closer to the optimum for grass than for the legumes (Wilson \& Ford, 1971), (Table 2). For $T$. repens there is evidence that the presence of $L$. perenne is beneficial for the development of the legume in younger pastures (Turkington \& Jolliffe, 1996).

In summary, only M. lupulina in monoculture produced a yield similar to T. repens at the harvests before and after winter and in mixture before winter. After winter, only T. repens produced a considerable yield in mixtures (Table 4).

\subsection{Initial Yield Phase}

A good establishment (Finch-Savage, 1995) of legumes associated with sufficient winter tolerance (Brouwer, Duke, \& Osborn, 2000) is the basis for a good yield and sufficient yield contribution in a mixture in the first main production year. In our experiments, T. repens and M. lupulina but also L. corniculatus showed a good 
establishment and winter tolerance (Tables 3 and 4). These three legumes also produced the largest accumulated yields in monocultures (Table 5). Despite a good establishment and winter tolerance, O. viciifolia in monoculture had a small accumulated yield in the main production year (Table 5). This may be due to the low cutting height $(3-4 \mathrm{~cm})$ and the high cutting frequency (five times in the main harvest year) in this trial. Onobrychis viciifolia is generally known to be susceptible to a low cutting height and in particular a frequent defoliation (Slepetys, 2008), although some authors also consider this species to be moderately tolerant to cutting (Briemle \& Ellenberg, 1994; see Table 1). Most likely, in our experiment a reduced cutting frequency of two to three cuttings per year would have increased the yield of $O$. viciifolia. The poor establishment and/or an inadequate or poor winter tolerance (Table 3 and 4) of M. falcata and L. uliginosus probably caused the only moderate accumulated yields in the first main harvest year (Table 5).

Table 5. Accumulated dry matter yield over the four harvests 2010 (Initial yield phase) of all species in pure and mixed stands with $L$. perenne (total yield and yield of the legume partner in the mixture) and coefficients of variation over these harvests

\begin{tabular}{|c|c|c|c|c|c|c|}
\hline \multirow[t]{3}{*}{ Plant species } & \multicolumn{3}{|c|}{ Accumulated dry matter yield $\left[\mathrm{g} \mathrm{pot}^{-1}\right]$} & \multicolumn{3}{|c|}{ Coefficient of Variation } \\
\hline & \multirow[t]{2}{*}{ Pure stand } & \multicolumn{2}{|c|}{ Mixed stand } & \multirow[t]{2}{*}{ Pure stand } & \multicolumn{2}{|c|}{ Mixed stand } \\
\hline & & Total & Legume & & Total & Legume \\
\hline L. corniculatus & $213.0 \pm 15.3^{\mathrm{b}}$ & $137.4 \pm 16.4^{\mathrm{cb}}$ & $21.8 \pm 15.3^{b}$ & $0.64^{\mathrm{a}}$ & $0.24^{\mathrm{ab}}$ & 0.95 \\
\hline L. uliginosus & $125.4 \pm 29.0^{\mathrm{c}}$ & $118.9 \pm 9.2^{\mathrm{c}}$ & n.p..$^{\#}$ & $0.56^{\mathrm{ab}}$ & $0.18^{\mathrm{b}}$ & n.p. \\
\hline M. lupulina & $239.3 \pm 33.3^{\mathrm{ab}}$ & $165.5 \pm 7.6^{\mathrm{b}}$ & $42.4 \pm 5.7^{\mathrm{b}}$ & $0.62^{\mathrm{a}}$ & $0.21^{\mathrm{b}}$ & 0.76 \\
\hline M. falcata & $192.4 \pm 18.2^{\mathrm{b}}$ & $121.0 \pm 9.0^{\mathrm{c}}$ & $9.9 \pm 2.2^{\mathrm{b}}$ & $0.69^{\mathrm{a}}$ & $0.20^{\mathrm{b}}$ & 0.85 \\
\hline O. viciifolia & $88.1 \pm 21.0^{\mathrm{c}}$ & $119.7 \pm 5.3^{c}$ & n.p. & $0.32^{\mathrm{c}}$ & $0.21^{\mathrm{b}}$ & n.p. \\
\hline T. repens & $288.6 \pm 12.2^{\mathrm{a}}$ & $253.3 \pm 53.9^{\mathrm{a}}$ & $149.0 \pm 63.8^{\mathrm{a}}$ & $0.39^{\mathrm{bc}}$ & $0.34^{\mathrm{a}}$ & 0.71 \\
\hline L. perenne & $115.4 \pm 10.1$ & & & 0.19 & & \\
\hline$P$-value & $<0.001$ & $<0.001$ & $<0.001$ & $<0.001$ & $<0.001$ & 0.395 \\
\hline
\end{tabular}

Shown are means and standard deviations. Different superscript letters indicate significant differences among species (ANOVA with Tukey Test $(a<0.05)$ analysis; the last row gives the corresponding $P$-values). $L$. perenne was not included the statistics. \# n.p.: not present; in these mixtures. The legume partner did not produce any more biomass at these harvests.

In mixtures, there was a positive linear correlation between the accumulated yield of the legume partner and that of the total mixture (grass and legume; $R^{2}=0.99 ; P<0.001$ ). T. repens was the most productive legume in mixtures with a yield proportion of nearly $60 \%$ of the total yield; this illustrates the strong competitive ability of $T$. repens (Petersen, 1967). A relative good competitive ability could be attributed to M. lupulina (Rehm \& Espig, 1991) with a yield proportion in mixture with $L$. perenne of above $25 \%$, while $L$. corniculatus had $16 \%$. Where the yield of legumes in mixtures was small, as for $M$. falcata, a species with low competitive ability against fast-growing grasses (Petersen, 1967), the total mixture yield was also only slightly increased compared to the grass monoculture, and even smaller than that of the legume monoculture (Table 5). When the legume partner was no longer present, as was the case with L. uliginosus and O. viciifolia, mixtures produced a similar accumulated yield as L. perenne in monoculture (Table 5).

In general, legumes require higher temperatures for optimal growth than L. perenne (Wilson \& Ford, 1971; Frame et al., 1998). Therefore, the growth of legumes in summer was faster compared to spring and autumn and yields differed between the harvests according to the individual temperature requirements of the respective legumes. This is well displayed in a higher coefficient of variation for the yields of all harvests for all six legumes in the main harvest year compared with the small CV for L. perenne (Table 5). In mixtures, the $\mathrm{CV}$ was depending on the legume partner and accordingly highest for the mixture with $T$. repens. In pure stands, $O$. viciifolia and $T$. repens showed the most stable yield over the first main production year.

\subsection{Outlook and Need for Research}

For the alternative legumes, an intensive breeding, like for T. repens in the last decades (Abberton \& Marshall, 2005), might help to enhance not only the yield potential but also the competitive ability in mixtures with fast 
growing grasses. A good and lasting contribution of the legume in grass-clover mixtures is essential for a successful introduction of new species.

This experiment provides some worthwhile information on early development of some legumes as possible alternatives to $T$. repens. Nevertheless, further work is necessary to test these legumes under field conditions with different cutting regimes, soil conditions and fertilizer applications. Of particular interest would be the reactions of these alternative legumes in view of possible future climate change conditions like drought or higher temperatures.

\section{Conclusion}

General, the yield in the first main productive year relies on a good germination and establishment along with a sufficient winter tolerance. Furthermore, the yield of a mixture strongly depends on the yield contribution of the legume partner. Thus, a good competitive ability of legumes against fast-growing grasses like L. perenne (Petersen, 1967) is essential.

In conclusion, M. lupulina and - to a somewhat lesser extent - L. corniculatus in monoculture showed potential to produce similar yields as $T$. repens in the first main production year, however, yield stability for M. lupulina and $L$. corniculatus was not sufficient. In mixtures, M. lupulina and less so L. corniculatus showed some potential, but only $T$. repens showed a strong competitive ability against $L$. perenne. This has to be considered with the choice of less competitive grass partner species when designing seed mixtures.

\section{Acknowledgment}

The authors thank the Ministry for Science and Culture of Lower Saxony, Hannover, Germany for the financial support. Furthermore we acknowledge the free supply with seeds by Feldsaaten Freudenberger GmbH \& Co. KG, Krefeld, Germany, Rieger-Hofmann GmbH, Blaufelden-Raboldshausen, Germany and DLF-Trifolium Deutschland GmbH, Hannover, Germany.

\section{References}

Abberton, M., \& Marshall, A. H. (2005). Progress in breeding perennial clovers for temperate agriculture. The Journal of Agricultural Science, 143, 117-135. http://dx.doi.org/10.1017/S0021859605005101

Alcamo, J., Moreno, J. M., Nováky, B., Bindi, M., Corobov, R., Devoy, R. J. N., ... Shvidenko, A. (2007). Europe. In M. L. Parry, O. F. Canziani, J. P. Palutikof, P. J. van der Linden, \& C. E. Hanson (Eds.), Climate Change 2007: Impacts, Adaptation and Vulnerability. Contribution of Working Group II to the Fourth Assessment Report of the Intergovernmental Panel on Climate Change (pp. 541-580). Cambridge, England: Cambridge University Press.

Argel, P. J., \& Paton, C. J. (1999). Overcoming legume hardseededness. In D. S. Loch, \& J. E. Ferguson (Eds.), Forage seed production. Volume 2: Tropical and subtropical species (pp. 247-265). Wallingford, England: $\mathrm{CAB}$ International.

Baker, H. G. (1972). Seed weight in relation to environmental conditions in California. Ecology, 53, 997-1010. http://dx.doi.org/10.2307/1935413

Brandsæter, L. O., Smeby, T., Tronsmo, A. M., \& Netland, J. (2000). Winter annual legumes for use as cover crops in row crops in northern regions: II. Frost resistance study. Crop Science, 40, 175-181. http://dx.doi.org/10.2135/cropsci2000.401175x

Briemle, G., \& Ellenberg, H. (1994). Zur Mahdverträglichkeit von Grünlandpflanzen. Möglichkeiten der praktischen Anwendung von Zeigerwerten. Natur und Landschaft, 4, 139-147. http://www.dnl-online.de/1905.html?dnlid=4484

Brouwer, D. J., Duke, S. H., \& Osborn, T. C. (2000). Mapping genetic factors associated with winter hardiness, fall growth and freezing injury in autotetraploid Alfalfa. Crop Science, 40, 1387-1396. http://dx.doi.org/10.2135/cropsci2000.4051387x

Crawford, E. J., Lake, A. V. H., \& Boyce, K. G. (1989). Breeding annual Medicago species for semiarid conditions in Southern Australia. In N. C. Brady (Ed.), Advances in Agronomy (Vol. 42, pp. 399-437). San Diego, USA: Academic Press, Inc.

Crews, T. E. \& Peoples, M. B. (2005). Can the synchrony of nitrogen supply and crop demand be improved in legume and fertilizer-based agroecosystems? A review. Nutrient Cycling in Agroecosystems, 72, 101-120. http://dx.doi.org/10.1007/s10705-004-6480-1

Dierschke, H., \& Briemle, G. (2002). Kulturgrasland. Wiesen, Weiden, und verwandte Staudenfluren. Stuttgart: Verlag Eugen Ulmer. 
Finch-Savage, W. E. (1995). Influence of seed quality on crop establishment, growth, and yield. In A. S. Basra (Ed.), Seed quality: Basic mechanisms and agricultural implications (pp. 361-393). New York, USA: Food Products Press.

Foulds, W. (1978). Response to soil moisture supply in three leguminous species I. Growth, reproduction and $\begin{array}{llll}\text { mortality. } & \text { New } & \text { Phytologist, } & \text { 50, }\end{array}$ http://dx.doi.org/10.1111/j.1469-8137.1978.tb01585.x

Frame, J., Charlton, J. F. L., \& Laidlaw, A. S. (1998). Temperate forage legumes. Wallingford, England: CAB International.

Hedqvist, H., Murphy, M., \& Nilsdotter-Linde, N. (2002). Tannin content and winter hardiness of birdsfoot trefoil and other tannin containing forage legumes grown in Sweden. In J. L Durand, J. C. Emile, C. Huyghe, \& G. Lemaire (Eds.), Grassland Science in Europe. Multi-function grasslands: quality forages, animal products and landscapes (Vol. 7, pp. 78-79). Poitiers cedex, France: Imprimerie P. Oudin.

Hopkins, A., Martyn, T. M., Johnson, R. H., Sheldrick, R. D., \& Lavender, R. H. (1996). Forage production by two Lotus species as influenced by companion grass species. Grass and Forage Science, 51, 343-349. http://dx.doi.org/10.1111/j.1365-2494.1996.tb02069.x

Hopkins, A., \& Wilkins, R. J. (2006). Temperate grassland: key developments in the last century and future perspectives. The Journal of Agricultural Science, 144, 503-523. http://dx.doi.org/10.1017/S0021859606006496

Jensen, E. S., \& Hauggaard-Nielsen, H. (2003). How can increased use of biological $\mathrm{N}_{2}$ fixation in agriculture benefit the environment? Plant and Soil, 252, 177-186. http://dx.doi.org/10.1023/A:1024189029226

Kemp, P. R. (1989). Seed banks and vegetation processes in deserts. In M. A. Leck, V. T. Parker, \& R. L. Simpson (Eds.), Ecology of soil seed banks (pp. 257-281). San Diego, USA: Academic Press, Inc.

Klotz, S., Kühn, I., \& Durka, W. (2002). BIOLFLOR - Eine Datenbank zu biologisch-ökologischen Merkmalen der Gefäßpflanzen in Deutschland. Schriftenreihe für Vegetationskunde, 38, 41-281. http://www2.ufz.de/biolflor/index.jsp

Moles, A. M., \& Westoby, M. (2004). Seedling survival and seed size: a synthesis of the literature. Journal of Ecology, 92, 372-383. http://dx.doi.org/10.1111/j.0022-0477.2004.00884.x

Peeters, A. (2009). Importance, evolution, environmental impact and future challenges of grasslands and grassland-based systems in Europe. Grassland Science, 55, 113-125. http://dx.doi.org/10.1111/j.1744-697X.2009.00154.x

Petersen, A. (1967). Klee und kleeartige als Kulturpflanzen, Wildpflanzen und Unkräuter auf Acker, Wiese und Weide. Berlin: Akademie-Verlag GmbH.

Rehm, S., \& Espig, G. (1991). The cultivated plants of the tropics and subtropics. Weikersheim: Verlag Josef Margraf.

Rochon, J. J., Doyle, C. J., Greef, J. M., Hopkins, A., Molle, G., Sitzia, M., ... Smith, C. J. (2004). Grazing legumes in Europe: a review of their status, management, benefits, research needs and future prospects. $\begin{array}{lllll}\text { Grass } \quad \text { Forage } & \text { Science, } & \text { 197-214. }\end{array}$ http://dx.doi.org/10.1111/j.1365-2494.2004.00423.x

Saatgutverordnung (SaatgutV). (2006). Verordnung über den Verkehr mit Saatgut landwirtschaftlicher Arten und Gemüsearten. In H. W. Rutz (Ed.), Sorten- und Saatgut-Recht (pp. 126-193). Bergen/Dumme, Germany: AgriMedia.

Slepetys, J. (2008). The productivity and persistency of pure and mixed forage legume swards. Latvian Journal of Agronomy, 11 http://llufb.llu.lv/conference/agrvestis/content/n11/AgrVestis-Nr11-276-282.pdf

276-281.

Sölter, U., Hopkins, A., Sitzia, M., Goby, J. P., \& Greef, J. M. (2007). Seasonal changes in herbage mass and nutritive value of a range of grazed legume swards under Mediterranean and cool temperate conditions. $\begin{array}{lllll}\text { Grass } \quad \text { and } & \text { Forage } & \text { 372-388. }\end{array}$ http://dx.doi.org/ 10.1111/j.1365-2494.2007.00592.x

Tauro, T. P., Nezomba, H., Mtambanengwe, F., \& Mapfumo, P. (2009). Germination, field establishment patterns and nitrogen fixation of indigenous legumes on nutrient-depleted soils. Symbiosis, 48, 92-101. http://dx.doi.org/10.1007/BF03179988 
Topp, C. F. E., \& Doyle, C. J. (2004). Modelling the comparative productivity and profitability of grass and legume systems of silage production in northern Europe. Grass and Forage Science, 59, 274-292. http://dx.doi.org/10.1111/j.1365-2494.2004.00427.x

Turkington, R., \& Jolliffe, P. A. (1996). Interference in Trifolium repens - Lolium perenne mixtures: short- and long-term relationships. Journal of Ecology, 84, 563-571. http://dx.doi.org/10.2307/2261478

Uzun, F., \& Aydin, I. (2004). Improving germination rate of Medicago and Trifolium species. Asian Journal of Plant

Sciences,

3 ,

714-717.

http://doaj.org/doaj?func=abstract\&id $=596841 \&$ recNo=13\&toc $=1 \&$ uiLanguage $=e n$

Wilkins, R. J., Gibb, M. J., Huckle, C. A., \& Clements, A. J. (1994). Effect of supplementation on production by spring calving dairy cows grazing swards of differing clover content. Grass and Forage Science, 49, 465-475. http://dx.doi.org/10.1111/j.1365-2494.1994.tb02024.x

Wilman, D., \& Williams, S. P. (1993). A comparison of grass/white clover and grass silages offered to dairy cows as the sole feed. Grass and Forage Science, 48, 231-237. 10.1111/j.1365-2494.1993.tb01856.x

Wilson, J. R., \& Ford, C. W. (1971). Temperature influences on growth, digestibility, and carbohydrate composition of two tropical grasses, Panicum maximum var. Trichoglume and Setaria sphacelata and two cultivars of the temperate grass Lolium perenne. Australian Journal of Agricultural Research, 22, 563-571. http://dx.doi.org/10.1071/AR9710563

Young, J. A., Evans, R. A., \& Kay, B. L. (1970). Germination characteristics of range legumes. Journal of Range Management, 23, 98-103. http://dx.doi.org/10.2307/3896108 